\title{
Knowledge and Attitude about Mental Illness of Students in a University in Southern Nigeria
}

\author{
Chidozie D. Chukwujekwu \\ Department of Neuropsychiatry, University of Port Harcourt Teaching Hospital, Port Harcourt, Nigeria \\ Email: chidozie.chukwujekwu@uniport.edu.ng
}

How to cite this paper: Chukwujekwu, C.D. (2018) Knowledge and Attitude about Mental Illness of Students in a University in Southern Nigeria. Journal of Biosciences and Medicines, 6, 95-104. https://doi.org/10.4236/jbm.2018.66007

Received: May 14, 2018

Accepted: June 23, 2018

Published: June 26, 2018

Copyright $\odot 2018$ by author and Scientific Research Publishing Inc. This work is licensed under the Creative Commons Attribution International License (CC BY 4.0).

http://creativecommons.org/licenses/by/4.0/ (c) (i) Open Access

\begin{abstract}
Objective: To ascertain the knowledge about mental illness and attitude of undergraduate students in a university in southern Nigeria, towards the mentally ill. Methods: This descriptive cross-sectional study was conducted at a Catholic University in Nigeria over a three-month period. 215 subjects were selected randomly from the total student population of 5045. A questionnaire containing socio-demographic variables and three subscales: The Knowledge about mental illness scale, Attitude to mental illness scale, Social Distance scale was administered to each subject. The data was analyzed using the Statistical Package for Social Sciences (SPSS) version 16.0. Results: Males (62.3\%), Christians (91.2\%), Igbos (49.5\%) and Single (93.0\%) constituted the largest proportions of the subjects. A majority of the subjects supported some of the common inaccurate stereotypes about mental illness. They exhibited obvious gap in knowledge with respect to symptoms of specific mental disorder. $42.8 \%$ were not sure of the biological cause of mental illness. Even though $80 \%$ of the subjects agreed that those suffering from mental illness should be helped, $48.8 \%$ maintained that they have little in common with them. Only $33 \%$ were willing to make friends with someone with a mental illness. Conclusion: Better ways of educating the youths to dissolve deeply entrenched negative cognitions about mental illness should be given premium attention by all stakeholders, especially in Africa.
\end{abstract}

\section{Keywords}

Stigma, Mental Illness, Knowledge, Attitude, Disorder

\section{Introduction}

Among the greatest contribution to the global burden of disease, psychiatric disorders rank significantly high. Nevertheless, ignorance of the nature, aetiolo- 
gy and outcome of mental disorders by the general public has led to poor attitude towards the mentally ill from time immemorial. This is because many people believe that mentally ill persons are dangerous, unpredictable and are less likely to be productive members of the community [1] [2]. These negative cognitions remain in spite of scientific breakthroughs that have helped us understand mental disorders better [3] [4].

It is worth noting that these negative attitudes and misperceptions are as old as mankind and are deeply entrenched from childhood through cultural myths and superstitions imbibed from the cradle. Stigmatization, rejection, ostracism, hostility and violence towards the mentally ill with attendant danger to the self esteem of the sufferers are some of the deleterious consequence of this unfortunate situation [5] [6]. History is replete with accounts of many unfortunate mentally ill perhaps labeled as witches, harassed, accused of causing pestilences and ill luck and some have faced gruesome execution [7] [8].

Many studies have been carried out in the developed world to assess the knowledge and attitude of the general public towards those suffering from mental illness [9] [10]. A few of such studies have been carried out in sub-Saharan Africa especially in the Western Nigeria [11] [12] and their results indicate that stigmatization of the mentally ill in a common phenomenon. Nevertheless there is paucity of such studies in the Niger Delta region of Nigeria. It is expected that availability of empirical data on this burning issue in the Niger Delta region will help in re-strategizing our advocacy initiatives for the mentally ill and will translate to a more effective anti-stigmatization campaign in the region.

\section{Methodology}

This descriptive cross-sectional study was conducted at the Madonna University Elele, Rivers State of Nigeria over a three month period from April-June 2016.

All the students of Madonna University Elele who were present in the school campus during the study period were included in the study. Those who were on an academic posting outside the school or those who were on holidays or ill were excluded to minimize the difficulty associated with the collection of completed questionnaires. Two hundred and fifteen (215) subjects were selected randomly from the total student population of 5045. These subjects consented to the study and hence had the research instruments administered to each of them.

\section{Research Instruments}

A standard questionnaire comprising demographic questions as well as scales adopted from previously published studies were utilized for this research.

The scales include:

\section{a) The Knowledge about mental illness scale (Wahl et al., 2011)}

This contains 17 factual statements about mental illness with which the participants agree or disagree using a 5-point Likert scale:

1) Strongly Disagree; 

2) Disagree;
3) Unsure;
4) Agree;
5) Strongly Agree.

b) Attitude to mental illness Questionnaire (Wahl et al.) [1].

It contains 17 items opinion statement about mental illness to which the participants will also agree with or disagree in a 5-point Likert format.

\section{c) Social Distance Questionnaire}

This is an 11 item questionnaire to which the participants will also respond to in a Likert format. The subjects were asked to indicate their degree of willingness to interact with a person suffering from a mental illness in a specific social situation. This scale was adopted from the Modified Bogardus Social Distance Scale (MBSDS) developed by Link [3] to better fit the lives of undergraduate students. The test retest correlations for overall scores for knowledge, attitudes and social distance were $0.49,0.74$ and 0.89 respectively [1].

Analyses of internal consistency yielded Cronbach's alpha of $0.63,0.83$ and 0.91 respectively $[1]$.

A modified version of this instrument comprising the first seven questions was used for this research.

Data analysis was carried out using the Statistical Package for Social Sciences (SPSS) version 16.0 (233 South Wacker Drive, $11^{\text {th }}$ Floor Chicago, Illinois 60606412 ) at $5 \%$ level of significance and $95 \%$ confidence interval.

\section{Results}

A total of 215 subjects participated and completed the study.

Table 1 shows the demographic characteristics of the subjects. The largest proportion of the subjects are male (62.3\%), Christian (91.2\%), Igbos $(49.3 \%)$ and single $(93.0 \%)$. The subjects were aged between 16 and $45 \mathrm{yrs}$ with a mean age of $22.93 \pm 5.878$ yrs

For simplification of results, the categories of responses were combined. The percentage of subjects reported as expressing agreement includes both "agree" and "strongly agree" responses. The percentage reported as expressing disagreement comprise "disagree" and "strongly disagree" responses. Similarly, for the social distance "willingness" include "definitely willing" and "probably willing" responses; and "unwillingness" includes the "definitely unwilling" and "probably unwilling” responses.

Table 2 shows that mental illnesses are not looked upon favourably. For example, $50.7 \%$ agreed that people suffering from mental illness are often treated unfairly while $57.2 \%$ agreed that mental illness is often portrayed negatively by the media. A majority of the students supported some of the common inaccurate stereotypes about mental illness, 59.6\% agreed that "psycho" and "kolo" are okay terms for mental illness while $73.7 \%$ agreed that people with mental illness tend to be violent and dangerous. 
Table 1. Demographic characteristics of the 215 subjects.

\begin{tabular}{|c|c|c|c|}
\hline$S / N$ & Characteristic & $\mathrm{N}$ & $\%$ \\
\hline \multirow{3}{*}{1} & Gender & & \\
\hline & Male & 134 & 62.3 \\
\hline & Female & 81 & 37.7 \\
\hline \multirow{4}{*}{2} & Religion & & \\
\hline & Christian & 196 & 91.2 \\
\hline & Muslim & 16 & 7.4 \\
\hline & Traditional & 3 & 1.4 \\
\hline \multirow{9}{*}{3} & Ethnicity & & \\
\hline & Hausa & 12 & 5.6 \\
\hline & Igbo & 106 & 49.3 \\
\hline & Yoruba & 28 & 13.0 \\
\hline & Ikwerre & 19 & 8.8 \\
\hline & Ogoni & 3 & 1.4 \\
\hline & Kalabari & 17 & 7.9 \\
\hline & Okrika & 2 & 0.9 \\
\hline & Others & 28 & 13.1 \\
\hline \multirow{5}{*}{4} & Marital Status & & \\
\hline & Single & 200 & 93.0 \\
\hline & Married & 11 & 3.8 \\
\hline & Separated/Divorced & 3 & 1.4 \\
\hline & Widowed & 1 & 0.5 \\
\hline \multirow[b]{2}{*}{5} & Age & \multicolumn{2}{|c|}{$22.93 \pm 5.878 \mathrm{yrs}$} \\
\hline & $\begin{array}{l}\text { Mean } \\
\text { Range }\end{array}$ & \multicolumn{2}{|c|}{$16-45 \mathrm{yrs}$} \\
\hline
\end{tabular}

Furthermore, the results indicated gap in knowledge with respect to symptoms of specific mental disorder. Almost half of the students (48.4\%) were unsure that schizophrenia involves multiple personalities only $9.3 \%$ disagreed with this. Similarly a significant proportion (40.0\%) were not sure if a person with bipolar disorder acts overtly energetically and $41.9 \%$ were not sure if most people with severe form of mental illness get better or not even with treatment. Furthermore $42.8 \%$ were not sure of the biological cause of mental illness.

Table 3 showed the attitudes about mental illness among the subjects. Over $80 \%$ of the subjects agreed that people with mental illness deserve respect and $92.1 \%$ agree that more should be done to help people with mental illness get better.

Nevertheless many negative attitudes were also exhibited by the subjects. Agreement with most of the items on the attitude questionnaire indicates a negative attitude of most subjects towards the mentally ill. More than one third of the subject were neither sure if they would be comfortable meeting a person with mental illness (38.6\%) nor if a person with mental illness would be a good friend (33.0\%). A greater proportion of the subjects (64.2\%) agreed that keeping people with mental illness in the hospital makes the community safer. $57.2 \%$ of the subjects stated that they would be frightened if approached by a mentally ill person. It is also noteworthy that $53.5 \%$ of the subjects insisted that students with 
Table 2. Knowledge about mental illness among the subjects.

\begin{tabular}{|c|c|c|c|c|c|c|c|}
\hline$S / N$ & Questionnaire Item & $\begin{array}{c}\text { Strongly } \\
\text { Disagree n\% }\end{array}$ & $\begin{array}{c}\text { Disagree } \\
\mathrm{n} \%\end{array}$ & $\begin{array}{c}\text { Unsure } \\
\text { n\% }\end{array}$ & $\begin{array}{c}\text { Agree } \\
\text { n\% }\end{array}$ & $\begin{array}{l}\text { Strongly } \\
\text { Agree n\% }\end{array}$ & Decision \\
\hline $\mathrm{K} 1$ & $\begin{array}{l}\text { "Psycho" and "Kolo" are okay terms } \\
\text { for mental illness }\end{array}$ & $22(10.2)$ & $36(16.7)$ & $29(13.5)$ & $78(36.3)$ & $50(23.3)$ & Agree \\
\hline K2 & $\begin{array}{l}\text { People with mental illness are hurt } \\
\text { by slang names for their disorder }\end{array}$ & $2(0.9)$ & $25(16.6)$ & $46(21.4)$ & $101(47.0)$ & $39(18.1)$ & Agree \\
\hline K3 & $\begin{array}{l}\text { Mental illness is not a very serious } \\
\text { problem }\end{array}$ & $117(54.4)$ & $59(27.4)$ & $11(5.1)$ & $19(8.8)$ & $3(1.4)$ & Disagree \\
\hline K4 & $\begin{array}{l}\text { Parents are usually to blame for a } \\
\text { child's mental illness }\end{array}$ & $40(16.6)$ & $87(40.5)$ & $55(22.6)$ & $28(13.0)$ & $3(1.4)$ & Disagree \\
\hline K5 & $\begin{array}{l}\text { People with mental illness are often } \\
\text { treated unfairly }\end{array}$ & $10(4.7)$ & $43(20.0)$ & $41(19.1)$ & $94(43.7)$ & $10(7.0)$ & Agree \\
\hline K6 & $\begin{array}{l}\text { Mental illness is often shown in } \\
\text { negative ways on TV and in movies }\end{array}$ & $15(7.0)$ & $26(12.1)$ & $50(23.3)$ & $103(47.9)$ & $20(9.3)$ & Agree \\
\hline K7 & $\begin{array}{l}\text { Psychological treatment (such as } \\
\text { talking to a psychologist or } \\
\text { counselor) is useful }\end{array}$ & $15(7.0)$ & $12(5.6)$ & $19(8.8)$ & $100(46.5)$ & $67(31.2)$ & Agree \\
\hline K8 & $\begin{array}{l}\text { People with mental illness tend to be } \\
\text { violent and dangerous }\end{array}$ & $8(3.7)$ & $17(7.9)$ & $32(14.9)$ & $113(52.8)$ & $45(20.9)$ & Agree \\
\hline K9 & $\begin{array}{l}\text { People with mental illness are more } \\
\text { likely to lie }\end{array}$ & $17(7.9)$ & $30(14.0)$ & $89(41.4)$ & $55(25.6)$ & $22(10.2)$ & Unsure \\
\hline $\mathrm{zK} 10$ & $\begin{array}{l}\text { People who have had mental illness } \\
\text { include astronauts, presidents, and } \\
\text { famous baseball players }\end{array}$ & $25(11.6)$ & $34(15.8)$ & $94(43.7)$ & $55(25.6)$ & $6(2.8)$ & Agree \\
\hline K11 & $\begin{array}{l}\text { Mental illness is often confused with } \\
\text { the effects of a drug abuse }\end{array}$ & $14(6.5)$ & $21(9.8)$ & $32(14.9)$ & $120(55.8)$ & $26(12.1)$ & Agree \\
\hline K12 & $\begin{array}{l}\text { Mental illness is caused by } \\
\text { something biological }\end{array}$ & $19(8.8)$ & $29(13.5)$ & $92(42.8)$ & $66(30.7)$ & $7(3.3)$ & Unsure \\
\hline K13 & $\begin{array}{l}\text { Giving medicine is a useful way to } \\
\text { treat mental illness }\end{array}$ & $4(1.9)$ & $21(9.8)$ & $31(14.4)$ & $124(57.7)$ & $29(13.5)$ & Agree \\
\hline K14 & $\begin{array}{l}\text { Mental illness and mental } \\
\text { retardation are the same thing }\end{array}$ & $35(16.3)$ & $83(38.6)$ & $44(20.5)$ & $46(21.4)$ & $7(3.3)$ & Disagree \\
\hline K15 & $\begin{array}{l}\text { A person with bipolar } \\
\text { (manic depressive disorder) acts } \\
\text { overt energetic }\end{array}$ & $4(1.9)$ & $20(9.3)$ & $86(40.0)$ & $88(40.9)$ & $15(7.0)$ & Agree \\
\hline K16 & $\begin{array}{l}\text { Most people with severe form of } \\
\text { mental illness do not get better even } \\
\text { with treatment }\end{array}$ & $13(6.0)$ & 47 (21.9) & $90(41.9)$ & $53(24.7)$ & $9(4.2)$ & Unsure \\
\hline K17 & $\begin{array}{l}\text { Schizophrenia involves multiple } \\
\text { personalities }\end{array}$ & $5(2.3)$ & $15(7.0)$ & $104(48.4)$ & $68(31.6)$ & $20(9.3)$ & Unsure \\
\hline
\end{tabular}

mental illness should not be in regular classes while $48.8 \%$ maintained that they have little in common with people who have mental illness. $67.5 \%$ stated that it would be embarrassing to have a mental illness.

Table 4 summarizes responses to social distance item. About half of the respondents $(52.5 \%)$ expressed a willingness to talk to someone with mental illness while only $33 \%$ were willing to make friends with someone with a mental illness. Only $16.8 \%$ were willing to have someone with mental illness as a neighbor, $22.3 \%$ were probably willing to sit next to someone with mental illness, $17.7 \%$ were willing to invite someone with a mental illness to their home. Only $7.9 \%$ 
Table 3. Activities about mental illness among the subjects.

\begin{tabular}{|c|c|c|c|c|c|c|c|}
\hline S/N & Questionnaire Item & $\begin{array}{c}\text { Strongly } \\
\text { Disagree } \mathrm{n} \%\end{array}$ & Disagree $\mathrm{n} \%$ & Unsure $\mathrm{n} \%$ & Agree n\% & $\begin{array}{l}\text { Strongly } \\
\text { Agree } \mathrm{n} \%\end{array}$ & Decision \\
\hline $\mathrm{A} 1$ & $\begin{array}{l}\text { People with mental illness deserve } \\
\text { respect }\end{array}$ & $5(2.3)$ & $19(8.8)$ & $17(7.9)$ & $130(60.5)$ & $44(20.5)$ & Agree \\
\hline $\mathrm{A} 2$ & $\begin{array}{l}\text { We should do more to help people } \\
\text { with mental illness get better }\end{array}$ & $5(2.3)$ & $5(2.3)$ & $5(2.3)$ & $112(52.1)$ & $86(40.0)$ & Agree \\
\hline $\mathrm{A} 3$ & $\begin{array}{l}\text { Jokes about mental illness are } \\
\text { hurtful illness }\end{array}$ & $4(1.9)$ & $11(5.1)$ & $40(18.6)$ & $114(53.0)$ & $42(19.5)$ & Agree \\
\hline A4 & $\begin{array}{l}\text { It is important to learn about } \\
\text { mental illness }\end{array}$ & $7(3.3)$ & $5(2.3)$ & $13(6.0)$ & $110(51.2)$ & $78(36.3)$ & Agree \\
\hline A5 & $\begin{array}{l}\text { A person with mental illness is able } \\
\text { to be a good friend }\end{array}$ & $13(6.0)$ & $30(14.0)$ & $71(33.0)$ & $73(34.0)$ & $25(11.6)$ & Agree \\
\hline A6 & $\begin{array}{l}\text { It is good idea to avoid people who } \\
\text { have mental illness }\end{array}$ & $28(13.0)$ & $87(40.5)$ & $42(19.5)$ & $46(21.4)$ & $10(4.7)$ & Disagree \\
\hline A7 & $\begin{array}{l}\text { I would be comfortable meeting a } \\
\text { person with mental illness }\end{array}$ & $13(6.0)$ & 47 (21.9) & $83(38.6)$ & $56(26.0)$ & $13(6.0)$ & Unsure \\
\hline A8 & $\begin{array}{l}\text { People with mental illness are able } \\
\text { to help others }\end{array}$ & $10(4.7)$ & $33(15.3)$ & $60(27.9)$ & $96(44.7)$ & $14(6.5)$ & Agree \\
\hline A9 & $\begin{array}{l}\text { I would be frightened if approached } \\
\text { by a person with mental illness }\end{array}$ & $20(9.3)$ & $38(17.7)$ & $33(15.3)$ & $103(47.9)$ & $20(9.3)$ & Agree \\
\hline A10 & $\begin{array}{l}\text { If I had a mental illness I would not } \\
\text { tell any of my friends }\end{array}$ & $22(10.2)$ & $61(28.4)$ & $70(32.8)$ & $49(22.8)$ & $10(4.7)$ & Unsure \\
\hline A11 & $\begin{array}{l}\text { If any friend of mine had a mental } \\
\text { illness I would tell him/her not to } \\
\text { tell anyone }\end{array}$ & $38(17.7)$ & $75(34.9)$ & 47 (21.9) & $43(20.0)$ & $11(5.1)$ & Disagree \\
\hline A12 & $\begin{array}{l}\text { Keeping people with mental illness } \\
\text { in the hospital makes the } \\
\text { community safer }\end{array}$ & $23(10.7)$ & $24(11.2)$ & $28(13.0)$ & $95(44.2)$ & $43(20.0)$ & Agree \\
\hline A13 & $\begin{array}{l}\text { Only people who are weak and } \\
\text { overly sensitive let mental illness } \\
\text { affect them. }\end{array}$ & $48(22.3)$ & $65(30.2)$ & $51(23.7)$ & $38(17.7)$ & $7(3.3)$ & Disagree \\
\hline A14 & $\begin{array}{l}\text { It would be embarrassing to have a } \\
\text { mental illness }\end{array}$ & $8(3.7)$ & $37(17.2)$ & $22(10.2)$ & $96(44.7)$ & $49(22.8)$ & Agree \\
\hline A15 & $\begin{array}{l}\text { Students with mental illness } \\
\text { shouldn't be in regular classes }\end{array}$ & $19(8.8)$ & $30(14.0)$ & $49(22.8)$ & $87(40.5)$ & $28(13.0)$ & Agree \\
\hline A16 & $\begin{array}{l}\text { I have little in common with people } \\
\text { who have mental illness }\end{array}$ & $23(10.7)$ & 37 (17.2) & $48(22.3)$ & $79(36.7)$ & $26(12.1)$ & Agree \\
\hline A17 & $\begin{array}{l}\text { Students with mental illness need } \\
\text { special programme to learn }\end{array}$ & $14(6.5)$ & $13(6.0)$ & $24(11.2)$ & $94(43.7)$ & $69(32.1)$ & Agree \\
\hline
\end{tabular}

were willing to work in a class project with someone with mental illness. Only $5.1 \%$ were willing to date someone with mental illness.

\section{Discussion}

The results for this study show that the students' knowledge about mental illness is apparently deficient. Even though a greater proportion is aware that mental illness is portrayed negatively by the media, majority of the students disappointingly endorse the common inaccurate stereotypes attributed to people with 
Table 4. Willingness to interact with someone with a mental illness among the subjects by social distance scale items.

\begin{tabular}{clcccccc}
\hline S/N & \multicolumn{1}{c}{ Questionnaire Item } & A n\% & B n\% & C n\% & D n\% & E n\% & Decision \\
\hline D1 & $\begin{array}{l}\text { Talk to someone with mental } \\
\text { illness }\end{array}$ & $10(4.7)$ & $31(14.4)$ & $37(17.2)$ & $102(47.4)$ & $11(5.1)$ & Willing \\
D2 & $\begin{array}{l}\text { Make friends, with someone } \\
\text { with a mental illness }\end{array}$ & $27(12.6)$ & $35(16.3)$ & $58(27.0)$ & $68(31.6)$ & $3(1.4)$ & Unsure \\
D3 & $\begin{array}{l}\text { Have someone with a mental } \\
\text { illness as a neighbor }\end{array}$ & $25(11.6)$ & $57(26.5)$ & $73(34.0)$ & $35(16.3)$ & $1(0.5)$ & Unwilling \\
D4 & $\begin{array}{l}\text { Sit next to someone with a } \\
\text { mental illness }\end{array}$ & $25(11.6)$ & $67(31.2)$ & $51(23.7)$ & $48(22.3)$ & $0(0.0)$ & Unwilling \\
D5 & $\begin{array}{l}\text { Invite someone with a mental } \\
\text { illness to your home }\end{array}$ & $25(11.6)$ & $82(38.1)$ & $46(21.4)$ & $37(17.2)$ & $1(0.5)$ & Unwilling \\
D6 & $\begin{array}{l}\text { Work in a class project with } \\
\text { someone with mental illness }\end{array}$ & $41(19.1)$ & $79(36.7)$ & $53(24.7)$ & $16(7.4)$ & $1(0.5)$ & Unwilling \\
D7 & $\begin{array}{l}\text { To go on a date with someone } \\
\text { with a mental illness }\end{array}$ & $42(19.5)$ & $89(41.4)$ & $48(22.3)$ & $11(5.1)$ & $0(0.0)$ & Unwilling \\
\hline
\end{tabular}

KEY: A= Definitely Unwilling; B = Probably Unwilling; C = Unsure; D = Probably Willing; E = Definitely Willing.

mental illness. They also subscribe to the notion that the mentally ill are prone to violence and dangerous. Their positions apparently stems from primordial assumptions about the unpredictability and tendency to violence attributed to the mentally ill; notions that have been held for along time now [1] [2]. In Africa, this is worse. As pointed out by Chukwujekwu et al., these negative primordial assumptions are based on ignorance and myth solely based on tradition and superstition [13].

It is also important to point out that the students demonstrated lack of knowledge about the symptoms of specific mental disorder. Only 9.3\% disagreed with the misconception that schizophrenia involves multiple personalities and $40.9 \%$ were unsure if overly energetic behavior is characteristic of Bipolar disorder. Similarly, $42.8 \%$ were not sure if mental illness has a biological cause. These findings are similar to result from previous studies [9] [10] [11] [12].

In the light of the foregoing, the need to educate students to recognize specific mental disorders and hence be able respond to them appropriately is required. However it is quite commendable that most of the students agreed that the use of pharmacotherapy is a useful way to treat mental illness. This is not surprising considering that there has been a greater shift from psychological to biological activity as management of mental disorders since half a century ago [4].

Nevertheless, it is disappointing that in the $21^{\text {st }}$ century and after more than 100 yrs of organized psychiatry, and ground-breaking advances in the aetiology and treatment of mental disorders, the students still exhibit significant lack of knowledge about mental disorders. Their pessimism about the treatment and recovery from severe mental illness further underscore this lack of knowledge and emphasizes that more need to be done in terms of education to erase deeply ingrained cultural myths and misconception about mental illness. 
It is remarkable that the students' activities to a large extent were negative. This is at variance with report by Wahl et al. [1]. It is a paradox considering that more than $80 \%$ of the students agreed that mentally ill persons deserve respect and that more should be done to help them. Surprisingly, the wide range of negative attitude expressed by a significant proportion of the students is a source of concern. More than a third of the subjects are neither sure if they would be comfortable meeting a person with mental illness nor if a person with mental illness could be a good friend. This is less stigmatizing than the results reported by Gureje et al. in a similar study carried out in which $96 \%$ of the subjects believed that people suffering from mental illness are dangerous and $82 \%$ maintained that they were afraid to have a conversation with a mentally ill patient [11]. A greater proportion subscribes to isolating the mentally ill to keep the community safer and that students with mental illness should not be in regular classes. They maintained that it would be embarrassing to have a mental illness and a significant proportion stated that they had little in common with people suffering from mental illness. These findings reflect the societal view about mental illness. It is not surprising considering the deficient knowledge and misconception about mental illness already expressed by the respondents. It is obvious that deficient and inadequate knowledge fuels stigma and prejudices. These in turn translate to the strong degree of social distance expressed towards the mentally ill by the students. More than half of the students were unwilling to talk to someone with mental illness. Only one third were willing to befriend someone with mental illness and less than a quarter would be willing to sit next to someone with mental illness. Less than a fifth were willing to have someone with mental illness as a neighbor or invite him to their home. Less than $10 \%$ were willing to work in a class project with someone suffering from mental illness or date such a person. These findings clearly indicate that the more intimate the relationship the less willing people are to relate with them. This corroborates previous results by Gureje et al. where only $16.9 \%$ of the respondents would ever consider marrying a mentally ill individual [11] while $41 \%$ of mentally ill patients reported that they experienced harassments of one form or the other according to Berzins et al. [7]. This unfortunate narrative concerning the mentally ill which is in keeping with the results of this study confirms the findings of Shibre et al. who reported that $75 \%$ of respondents perceived they were stigmatized because they were related to someone who was mentally ill, $42 \%$ maintained that they were being treated with difficulty and $37 \%$ confessed that they would prefer to conceal their family history of mental illness [12]. This underlies the substantial rejection these patients still suffer in the $21^{\text {st }}$ century.

Considering that the study was carried out in a Catholic University, in Nigeria, it is disheartening that in spite of several decades of western education and emphasis on religious morals, the mentally ill still suffers so much rejection. If the students who are supposedly enlightened react this way towards the mentally ill, one can only imagine the degree of rejection the mentally ill suffer in the hands of the illiterate majority in our population. This underscores the enormity 
of the problem and the urgency this hydra-headed problem deserves.

\section{Limitations}

This study was carried out in a Catholic University. It is possible that religious dogmas may have played a role in the views and attitude of the respondents towards mental illness. Therefore its application to the general population should be done with caution.

\section{Conclusion}

The study attempts to objectively assess young people's knowledge and attitude about mental illness. Results show that the knowledge young people have about mental illness is clearly deficient. Their lack of understanding of the nature and symptoms of mental illness make them unable to recognize these disorders appropriately and hence proffer help. Furthermore, attitudes expressed towards the social acceptance of peers with mental illness were substantially negative. This in turn fuels self stigma by the sufferers. Better ways of educating the youths to dissolve deeply entrenched negative cognitions about mental illness should be given premium attention by all stakeholders. This will be the only hope to see a future generation with the right attitude towards the mentally ill and hence translate to better management and outcome for the mentally ill.

\section{Acknowledgements}

I wish to appreciate Efa, Alfred and Tochukwu for their assistance in retrieving the questionnaires from the subjects. I should also mention Mrs. Elizabeth Mathew for painstakingly typing the manuscript.

\section{References}

[1] Wahl, O., Susan, J., Lax, A., Kaplan, L. and Zatina, D. (2012) Knowledge and Attitude about Mental Illness: A Survey of Middle School Students. Psychiatric Series, 63, 649-654. https://doi.org/10.1176/appi.ps.201100358

[2] Corrigan, P.W., Ed. (2005) On the Stigma of Mental Illness: Practical Strategies for Research and Social Change. American Psychological Association, Washington DC. https://doi.org/10.1037/10887-000

[3] Link, B.C., Phelan, J. and Bresnahan, M. (1999) Public Conceptions of Mental Illness: Labels, Causes, Dangerous and Social Distance. American Journal of Public Health, 89, 1328-1333. https://doi.org/10.2105/AJPH.89.9.1328

[4] Pescosolido, B.A., Martin, J.K., et al. (2010) A Disease Like Any Other: A Decade of Change in Public Reactions to Schizophrenia, Depression and Alcohol Dependence. American Journal of Psychiatry, 167, 1321-1331. https://doi.org/10.1176/appi.ajp.2010.09121743

[5] Kranke, D. and Floersch, J. (2009) Mental Health Stigma among Adolescents, Implication for Social Workers. School of Social Work Journal, 34, 28-42.

[6] Moses, T. (2010) Stigma and Self Concept among Adolescents Receiving Mental Health Treatment. American Journal of Orthopsychiatry, 79, 261-274. https://doi.org/10.1037/a0015696 
[7] Berzins, K.M., Petch, A. and Atkinsan, J.M. (2003) Prevalence and Experience of Harassment of People with Mental Health Problem Living in the Community. British Journal of Psychiatry, 183, 526-533. https://doi.org/10.1192/bjp.183.6.526

[8] Kelly, L. and Mckenna, H. (1997) Victimization of People with Enduring Mental Illness in the Community. Journal of Psychiatry and Mental Health Nursing, 3, 185-191. https://doi.org/10.1046/j.1365-2850.1997.00054.x

[9] Carrigan, P.W. and Watzan, A.C. (2002) Understanding the Impact of Stigma on People with Mental Illness. World Psychiatry, 1, 16-20.

[10] Crips, A.H., Gelder, M.G. and Rix, S. (2010) Stigmatization of People with Mental Illness. British Journal of Psychiatry, 177, 4-7.

[11] Gureje, O., Lasebikan, V.O., Ephraim-Oluwanuga, O., Olley, B.O. and Kola, L. (2005) Community Study of Knowledge and Attitude to Mental Illness in Nigeria. British Journal of Psychiatry, 186, 436-441. https://doi.org/10.1192/bjp.186.5.436

[12] Shibre, T., Negash, A. and Kullgren, G. (2001) Perception of Stigma among the Family Members of Individuals with Schizophrenia and Major Affective Disorder in Rural Ethiopia. Social Psychiatry and Psychiatric Epidemiology, 36, 299-303.

[13] Chukwujekwu, D.C. and Stanley, P.C. (2008) Patterns of Aggression among Psychiatric in Patients at the Jos University Teaching Hospital. Journal of Medicine in the Tropics, 10, 7-13. 